\title{
4. The challenge of teaching Australian history
}

\section{Anna Clark}

\begin{abstract}
When Prime Minister John Howard gave his speech to the National Press Club on the eve of Australia Day in 2006 he called for a 'root and branch renewal' of history teaching in our schools. 'In the end,' he said, 'young people are at risk of being disinherited from their community if that community lacks the courage and confidence to teach its history.' Nation-building is often conceived in very tangible forms - engineering marvels, wars, and even national institutions can claim credit for helping to define the nation's legacy. Teaching the nation's history in schools also raises questions of national definition. But what story of Australia do we want to teach in schools? This chapter examines recent public debates over Australian history teaching and argues that meaningful nation-building will not arise from a simplistic promotion of Australian nationalism, but by encouraging genuine critical engagement with the past.
\end{abstract}

\section{Introduction}

On the eve of Australia Day in 2006, then Prime Minister John Howard spoke at the National Press Club in Canberra with a 'state of the nation' style address celebrating Australia's democracy, economy and national identity - the 'Australian Achievement', in his words. The speech was also a call to protect that achievement: more than ever, Howard maintained, Australia required greater national cohesion and identification.

One of the keys to that cohesion would come from a more consistent national history education. Howard lamented the state of historical knowledge and national connection among Australian schoolchildren. Australian history had become lost in a stew of 'themes' and 'issues', he said, and required a 'root and branch renewal' to restore its proper place in the curriculum. ${ }^{l}$ It was hard to disagree with his sentiment: Australian history education is largely inconsistent and uncoordinated. With the possible exception of New South Wales, students around the country learn patchy, repetitive versions of the nation's past that chop and change between topics. Often they just learn the same things again and again. They are indeed alienated from their nation's past.

Yet this wasn't simply a call for curriculum restructure. Howard wanted a renewal of history education to promote 'Australianness' to the nation's youngest citizens - 'our children'. The Prime Minister regretted that the subject had 'succumbed 
to a post-modern culture of relativism where any objective record of achievement is questioned or repudiated' ${ }^{2}$ What was needed, he said, was a stronger, more positive national story for Australian schools. Such a position isn't surprising. Many Australians share the view that a nationally affirming history education is essential for national cohesion and identity - essential for nation-building, in fact. My concern is that any understanding of history education as 'nation-building' actually reduces the capacity for critical reflection and understanding among students; and that these are the very qualities of citizenship that we should be fostering in a democracy.

\section{History for the future}

In his 2006 Australia Day address, the then Prime Minister, John Howard, explained how teaching the nation's past was key to any effort to sustain Australia's identity and national ethos. 'Part of preparing young Australians to be informed and active citizens is to teach them the central currents of our nation's development,' he insisted. In other words, not teaching this national story could threaten the future of the nation itself: 'young people are at risk of being disinherited from their community if that community lacks the courage and confidence to teach its history' ${ }^{3}$

Coming so soon after the Cronulla riots in December 2005, the timing and tone of Howard's speech was pointed: social cohesion was not the product of good fortune but conscientious and collective efforts. A number of influential commentators also picked up on Howard's reference to the riots a couple of months earlier, and connected his call for a more systematic and nationally affirming history education with these divisive demonstrations. ${ }^{4}$ The Cronulla riots embroiled hundreds of young Australians in disturbing scenes of violence, drunkenness and racism masquerading as patriotism. They also confirmed an apparently fractured national identity that many Australians, including the Prime Minister himself, found worrying and extreme. ${ }^{5}$

Howard's Australia Day speech responded directly to these divisions in Australia, and suggested that they threatened the fabric of the nation's future. While he acknowledged that 'Australia's ethnic diversity is one of the enduring strengths of our nation', he offered the following caution: 'our celebration of diversity must not be at the expense of the common values that bind us together' ${ }^{6}$ Those common values had to be deliberately cultivated, he reasoned, and the history curriculum was a natural place for promoting Australia's shared identity and heritage. While the Prime Minister shied away from advocating an overly celebratory history education, he believed in the fundamental importance of a distinct national narrative for schools that was ultimately affirming: teaching the nation's story was critical to ensuring its strength and identity. 
References to nation-building conjure up images of bridges, irrigation projects and even institutions - those building blocks that are tangible tributes to national strength and prosperity. And taken together, they form a sort of narrative of nation-building, if you like, documenting its triumphs and contributions over time. In Howard's Australia Day speech we had another sort of nation-building narrative - less tangible, perhaps, but no less real. This was the nation-building potential of 'history' itself. For nations are built on stories that their peoples collectively believe in and aspire to as an 'imagined community', to use Benedict Anderson's famous phrase. ${ }^{7}$ And there was a strong underlying message in Howard's speech that without this story of the 'Australian Achievement', young people risked being nationally illiterate.

He had plenty of supporters. The historian Gregory Melleuish applauded the Prime Minister's 'vision for a new style of Australian history'. For too long the subject has often 'had as its main objective the indoctrination of students into a set of narrow dogmas,' he cautioned, but Howard 'has provided the outline of an Australian history that is humane and open-minded in approach, and which will enlarge the outlook of our young people. Let us hope that a 'coalition of the willing' emerges to make this vision a reality. ${ }^{\prime}$ In another article for The Australian, Janet Albrechtsen was similarly unequivocal: 'there is much work to be done in undoing the progressive curriculum foisted on Australian schoolchildren' ${ }^{9}$

Members of the public also supported the Prime Minister's announcement as evidenced in correspondence to major Australian dailies and weblog postings. In a letter to the Adelaide Advertiser Grattan Wheaton agreed 'with everything Mr Howard said about the teaching of history/geography subjects in schools' ${ }^{10}$ Contributing to Andrew West's weblog in the online edition of the Sydney Morning Herald, some eager bloggers also backed the Prime Minister's history initiative. 'In my opinion, history should be a mandatory subject during a person's education,' offered 'Lexa'. 'With all the "Aussie Pride" of Australia Day and the togetherness that is being touted around, perhaps it would be easier to implement if people KNEW what they had to be proud of.' ${ }^{11}$

Comments like these were by no means isolated. There is a powerful popular sentiment that the role of national history is to strengthen the nation itself. Correspondingly, the role of history education is commonly held to bolster that national story by passing it on to the next generation. ${ }^{12}$ So when the former Education Minister, Julie Bishop, announced a national history summit a few months after Howard's Australia Day address, there were similar messages of support published in newspapers, online journals and discussions around the country. Comprising eminent historians and public commentators from around the country, the Australian History Summit was proposed to develop a new national approach to teaching the nation's past. 'The time has come for a 
renaissance in the teaching of Australian history in our schools,' Bishop insisted. 'By the time students finish their secondary schooling, they must have a thorough understanding of their nation's past.'13

In a letter to The Australian, Jenny Hammett commended the minister's summit initiative: 'I am frequently staggered by how little people know of our history. Australia has a richness of history full of the drama, tragedy and joy of human experience. It is a unique tapestry that for too long has been hijacked by the self-interest of those who seek to force a dominant view and have stifled argument by controlling the education of our children.' ${ }^{14}$ Another correspondent to The Australian, Miranda Kelly, expressed similar concern: 'How can we, as a nation, possibly expect to compete on the world stage if Australian history - warts and all - is not taught as a compulsory subject in our schools?' she asked. 'If not, we face the tragic reality that our future leaders will have no idea how our nation developed.' 15

Such support was hardly unexpected. The urge to teach the 'Australian Achievement' in schools is a position that many Australians of varying political persuasions actively share. They see the role of history education is precisely to educate 'tomorrow's citizens' about their national heritage and identity. It is the conduit for developing knowledge and pride in the nation and its past and any failure to connect with our national story is seen as a threat to the identity, strength and future of the nation itself.

It is not my intention to dismiss these popular understandings of history's national importance, for this belief in the nation-building potential of history education is widely and deeply held across the political spectrum. I also think it is misleading to suggest that 'mainstream Australia' has been manipulated by some sort of conservative political campaign to redefine Australian values. Like Judith Brett, I sense that 'ordinary Australians' have helped shape the past decade in Australian political life, as much as they have been defined by it. ${ }^{16}$

But I remain concerned if Australian history teaching is coopted to promote or instil any national affiliation that is automatic, rather than reflective. History education is uniquely placed in the culture wars over 'Australianness' because it is the only place that citizens are formally presented with their nation's past. Despite the obvious inconsistencies in the delivery of history education, in one form or another, students learn about their national heritage and identity in thousands of schools around the country - that is why claims to define approaches to Australian history education generate such heated public debate. Nevertheless, I argue that the current problems of history teaching around the country must not be met with a narrowly 'national' curriculum response.

When Howard concluded his 2006 Australia day speech with some words from history, he was laying out what he hoped would be a return to the 
nation-building hopes and beliefs of previous generations: 'we should also affirm the sentiment that propelled our nation to Federation 105 years ago - one People, One Destiny', he pledged. ${ }^{17}$ But there are significant pedagogical problems with such expressions of history's national potential and importance: while I agree that understanding the nation's past is essential for all students, I also want them to learn about history as a discipline - above and beyond any 'Australian story' or core national knowledge. I'm aware that this desire for a more complex approach to the subject rubs uneasily against the widespread belief in teaching an Australian history that strengthens the nation rather than critiques it. But it is clear that historical understanding and awareness do not come from parochial national knowledge. Indeed, the term 'historical literacy' does not mean demonising or demolishing the national past, but it does require a capacity to reflect upon it.

\section{Historical literacy}

The problem with any nationally affirming approach to history education is that it fails to encompass the disciplinary components of the subject: why do people disagree over Australian history, for example? And how do we deal with these contrasting historical interpretations? Such questions go beyond any specific national role for history teaching to consider deeper questions about the nature of history itself - and that means encouraging students to think about history beyond their national past. History is much more than an account of 'what happened'. It offers a deeper understanding of national values and identity rather than simply confirming them in class.

While most responses to Howard's Australia Day speech agreed that Australian history was in urgent need of curriculum support and renewal, a number of historians and educators qualified their support by emphasising a more complex approach to the discipline. Speaking on the ABC's 7.30 Report, historian, Stuart Macintyre, acknowledged the need for a stronger national history curriculum, so long as that was not at the expense of critical engagement in the classroom. 'I think we would all agree that we need to do more to restore history,' he acknowledged, 'but we need to make sure that that is open to diverse viewpoints and that it is not simply an exercise in indoctrination.' ${ }^{18}$ Historian Graeme Davison went one further and insisted that any national benefit from the subject in fact depended on history's capacity to generate engaged discussion and debate among students. History's worth in a liberal democracy lies in its capacity to develop critical thinking: 'We cannot inculcate democratic values in the polity unless we encourage critical and independent judgement in the classroom.' ${ }^{19}$ Annabel Astbury, professional services manager at the History Teachers' Association of Victoria, similarly hoped that history's complexity would not be overlooked by any emphasis on the Australian story. 'A history class free from 
question and repudiation therefore does not augur well in producing "good citizens"', she warned. $^{20}$

Some public contributors to the discussion also questioned any emphasis on 'national facts' at the expense of more complex engagement. 'Certainly, it's a fact that Federation occurred in 1901,' wrote Daniel Berk in a letter to The Australian, 'but are the reasons behind this historic event 'facts' or opinions? That event was the product of a whole host of different opinions that motivated people to behave and interact in various ways, with Federation as the end result.' $^{21}$ Contributing to an online discussion hosted by the Age newspaper, 'Kim' posted this response: 'History is seen and told differently by the different sides and participants, so while facts are important and should be taught, theory, discussion, arguments and debates should also be encouraged. ${ }^{22}$

Meanwhile, other commentators wondered about the potential parochialism of any national history emphasis. Robert Manne said he thought it was 'more important for historical literacy and for citizenship to have a rough working knowledge of what's happened in the world' ${ }^{23}$ The historian Clare Wright was similarly doubtful about any possible emphasis on prescribed facts in an Australian history education at the expense of skills: 'I'm all for the compulsory teaching of Australian history in schools,' she argued. 'But planting the seeds of ideas and learning means more than getting the facts straight.' 24

Comments such as these begin to define an understanding of history that moves to a more complex consideration of national benefit through critical engagement. Such a view contends that history can help us understand why people disagree over the past, and why historical interpretations change over time. Indeed, it confirms that history is as much about contemporary values as it is about trying to understand events, ideas and beliefs from another time and place.

History educationists have attempted to codify these complex skills of historical understanding in a way that enables students to learn about the importance of the subject while retaining its complexity in the classroom. This doesn't mean the facts are not important, or that the national story should not be taught. Of course students need to know 'what happened' in Australia's past. But they should also engage with the discipline beyond that national knowledge. This is a call for 'historical literacy', a term I borrow from history educationists Tony Taylor and Carmel Young. They acknowledge that knowing the nation's story is essential — but so too is learning historical skills, reconciling different perspectives and developing students' own judgements and ideas about the past. 25

The concept of historical literacy builds on research by North American scholars such as Peter Seixas and Sam Wineburg, who argue that the value of history education lies precisely in its complexity. Simplistic national affirmations actually 
cease to be 'history' because they forego the fundamental elements of the discipline such as critical engagement, understanding why historical interpretations differ, and reconciling the values of the past with the present. School history 'should provide students with the ability to approach historical narratives critically', Seixas explained. 'We need to teach students to think historically.' ${ }^{26}$ Wineburg has similarly criticised what he termed the 'textbook mentality' of history education, which presumes national historical knowledge simply needs to be known rather than understood. ${ }^{27}$

These pedagogical approaches to the subject insist on teaching an approach to history that can accommodate contrasting opinions and shifting understandings. To that end, says Seixas, 'This is the promise of critical historical discourse: that it provides a rational way, on the basis of evidence and argument, to discuss the differing accounts that jostle with or contradict each other.' That means 'it would be self-defeating to attempt to resolve these arguments before we get into the classroom, in order to provide students with a finished truth,' he continued. 'Rather, we need to bring the arguments into the classroom.' 28

The work of Peter Lee and Ros Ashby in the United Kingdom has also questioned any approach to history education limited to nation-building. Again, this doesn't mean national content is irrelevant, but for history education to have intellectual merit beyond national affiliation it must have an intellectual component. 'Students need to know about the past or the whole exercise becomes pointless,' Lee acknowledged. 'But understanding the discipline allows more serious engagement with the substantive history that students study, and enables them to do things with their historical knowledge. ${ }^{29}$

By encouraging this deeper approach to the past, the nation-building potential of history education lies in its capacity to develop a national engagement that stems from students themselves. This is certainly the belief of American scholars Linda Levstik and Keith Barton, who both confirm the democratic potential of the subject, and insist that it is 'uniquely privileged to provide the shared sense of national identity necessary for democratic participation. ${ }^{30}$ Indeed a complex history education is needed to cope with a complexity of voices and perspectives in a liberal democracy. ${ }^{31}$

This is not to say I am unsupportive of a more consistent and coordinated national story for schools. Historical literacy demands that students need content and context to engage with the past, and knowing Australian history is fundamental to that context for Australian students. But they also need to be able to work with this history. Students and teachers deserve a subject that expands their historical understanding and analysis, rather than limits it to a project of patriotism - and it is to the classroom that I finally turn to consider their thoughts on history's place in Australia. 


\section{'Doing' history in the classroom}

For the past two years I have been directing a large ARC funded research project about history teaching. ${ }^{32}$ The research was developed in response to some of these national concerns over history teaching - generated in particular by a popular belief in the subject's nation-building potential.

In all, 246 high school students, history teachers and curriculum officials from each of the eight Australian States and Territories were interviewed for this research. (I have also interviewed around 80 respondents from four provinces in Canada as a part of comparative study.) This qualitative study did not set out to present yet another statistical survey of what students do not know about their national past. Rather, these classroom perspectives challenge assumptions that the national benefit of Australian history education lies in doing 'more of it' or returning to 'the basics' of an affirming national narrative. It is not that the students I spoke with question the importance of their nation's heritage far from it - but they do have strong opinions about what it offers them and other young Australians.

Overwhelmingly, these students support the teaching of Australian history in school. When I asked a group of boys at an Islamic school in Western Sydney whether Australian history should be a compulsory subject, Oyuz thought it probably should, 'Because it's good to know what happened in the past'. His classmate Ahmed captured the sentiment even more strongly: 'It's not just good to know,' he said, 'we should know. ${ }^{33}$ Jill, a year nine student from a public school on the New South Wales Central Coast, thought that everyone should study Australian history. 'I can't understand why other states don't learn about it,' she said, 'because it's really important that we do'. 34

Even those students who doubted the effectiveness of mandatory Australian history per se sensed the importance of the subject. Jill's classmate Les said that he didn't think the subject should be mandated, because 'I've always found from personal experience that if you try and make things compulsory it's the fastest way to make people not interested'. But he acknowledged that 'you have to Australian history' in some form. ${ }^{35}$ Chen, a year 11 student at a public girls' school in Sydney was similarly ambivalent about the extent of any exclusively national historical education, but she thought it was nevertheless essential to teach: 'Yeah, I think it should be compulsory, like at one stage of your life, but not like throughout your primary school and throughout your high school. ${ }^{36}$

Despite this widespread acknowledgement by students that Australian history should be taught, they didn't suggest its value comes from any parochial or chest-thumping patriotism. In fact, the opposite is almost certainly true: time and again, students described their understanding of the subject's importance in terms of learning about Australia in an international context, considering 
multiple perspectives, and engaging in more open-ended learning. At an independent girls' in Canberra, for example, Annie thought Australian history should be compulsory in school, but that a broader and more critical context would make it more engaging for students: 'I think that we need to move away from the Australian perspective because we are not the only country in the world, whatever they might have us believe. And maybe just [have] more discussions as well. ${ }^{37}$

For so many of these students, history's worth stems from how it helps them to think, above and beyond any core national knowledge. When I spoke with a group of students from a girls' school in Brisbane, Lily thought history was 'different to a subject like maths and stuff, because you can look at it and interpret it'. That interpretation 'may not be the same as the person next to you,' she said, 'but it doesn't mean it's wrong'. 38 Jeff goes to a Catholic boys' school in Brisbane and also thinks the subject is more engaging 'with the student going out and being a proactive learner, rather than the teacher sort of feeding them information'. 39

That's not to say students would prefer laissez-faire discussion-based lessons with no content at all. But they're critical of approaches to the subject that preclude any historical engagement from them. Maddison, a year 12 student from Perth, did not like learning history when the lessons were 'Entirely textbook focused. I mean, textbooks are important for a lot of it, but entirely textbook - especially the textbooks we get - is horrible.' 'Yeah,' said his classmate Eva, 'I don't like the kind of style where you just read and answer questions. It's okay if you're reading and kind of talking about it.' 40

\section{How do you learn history best?}

Many Australians believe the purpose of Australian history teaching is essentially nation-building. Yet in classrooms around Australia students want a much more complex appreciation of the subject, where knowing the nation's past and critically engaging with it are not mutually exclusive. These year 12 students a public school in Darwin recognised the place for learning historical content, but they also wanted teaching methods that included and encouraged different points of view:

Daniel: We've never really had anything other than classroom discussions.

Natalie: We did a lot of debating last year, like arguing our different sides, and I think one of the really big components is having good teachers. I think what made that so interesting was that we had really good teachers who know their stuff and have like actively engaged us and they've questioned our opinions, and it's just been a really good experience. 
Gabby: I think on the whole, I don't want to speak for everyone in our history class, but I get the feeling that we all learn better through the discussions.

Others: Yes.

Gabby: Through being able to ask those questions and that sort of thing, rather than just reading dates out of a textbook. Although that is helpful in some instances, I think as a whole a lot of our learning has been through discussion. ${ }^{41}$

Comments such as these are vital in the midst of these public and political debates over history teaching. Indeed, far from being challenged by the possibility of multiple perspectives, the students I spoke with overwhelmingly say that's how they learnt history best.

Teachers also understand the importance of learning both the content and skills of historical inquiry. And, like their students, they are not sure that teaching a more nationally-oriented curriculum is necessarily the answer. In Tasmania, Margaret thought that Australian history should be compulsory, but she wasn't convinced by the current public discussions about core national knowledge. 'There are basics about geography and history that kids need to understand who they are,' she insisted. 'But I never want to see a situation that says you'll teach this to this person on this day and in this way, because you have to come from where kids are at.' She was exasperated by the political pressure that had been generated following Howard's 2006 Australia Day speech: 'Oh look, you read in the paper all the time about the history the kids should know and I keep thinking, "Right, come into a classroom and teach it". It doesn't work. ${ }^{42}$

By contrast, at a public school in Brisbane, Mary says the reward for teaching historical complexity is when her history classes really come alive: 'It's fun, it's good - you create critical kids,' she explained. 'The really bright ones will actually learn to challenge you as well as the texts and the sources and stuff. ${ }^{43}$ Stephen from Adelaide was similarly open about the skills of critical analysis he hoped to instil in his students: 'I like students to think, I like them to be critical thinkers. I like them to question what they're being fed, and even question what I might say to them as well. ${ }^{\prime 4}$ Such classroom perspectives provide a stark contrast to the public calls for an affirming and exclusive national approach to the subject.

These teachers and students acknowledge the importance of teaching Australian history, but they expressed real concern about implementing a narrowly national approach to the subject. The limitations of history teaching for nation-building certainly weren't lost on these students at a Catholic boys' school in Perth. In fact, they sensed the merits of the subject lay precisely outside any narrowly national appeal: 
Q. Do you think Australian history should be a compulsory subject?

Adrian: I don't think it should be to the extent that American history has been taught. Like I think it should still be taught from the perspective that it's open to interpretation.

Brendan: Yeah, I think if it's compulsory, it shouldn't be inward-looking like America, and I think it should be the whole investigative sort of history. I don't like the idea of just learning facts, and then being told what to think.

Jeff: Because that would be boring.

At a public girls' school in Sydney, Andie also thought the subject's interest and importance depended on understanding its complexity and encouraging the questions it raised in class:

For me, it sort of puts everything into perspective, because in other subjects it's sort of like me, me, me, and sort of like thinking in a small scale, but in history you can think in a really broad scale. It's not that we're insignificant, but in a global scale we've lived for so many years and people have done so many great things, it's just really interesting to learn about it. ${ }^{45}$

Such comments reveal that discussions of history's value beyond any national appreciation are not restricted to the academy. The teachers and students I spoke with certainly understand the complexities of history education - what is more, they suggest, the subject is more interesting and engaging for it. And that means fostering history classes that not only connect students to Australia's past, but also help them become critical thinkers who can engage with challenging ideas and different points of view. When I asked the group of students from the New South Wales Central Coast whether they enjoyed studying history, Les was effusive: 'I love it', he said. 'I really like the flexibility in history because you can look at everything and there's no direct answer.' Added Ryan: 'And everyone's allowed to have their own opinions. Like, you're allowed to have yours - I don't care — as long as you can kind of back up your evidence. ${ }^{.46}$ This critical capacity, I argue, is exactly the sort of 'nation-building' that Australian history education should encourage.

\section{Conclusion}

Many Australians believe history should be a source of pride, and that young people should have an affirming national story with appropriate values to aspire to. Yet we also require space for these national narratives to be critically discussed in class. While there is no doubt Australian history should be an essential component of young Australians' school education, we need to ensure their historical understanding is expanded rather than limited it to any simplistic or 
uncontested national narrative. And that means a fundamental reconsideration of history teaching away from the nation-building rhetoric of the 'Australian Achievement' to a more complex engagement with Australian history and identity. For it is with those skills of inquiry and analysis that any real nation-building potential of Australian history will be realised - and, perhaps surprisingly, many students say just that. So shouldn't we be offering a national history that students feel they are helping to define?

\section{References}

Albrechtsen, Janet. 2006. 'Textbook case of making our past a blame game.' Australian, 1 February.

Anderson, Benedict. 1991. Imagined Communities: Reflections on the Origin and Spread of Nationalism. 2nd ed. London, New York: Verso.

Astbury, Annabel. 2006. 'A lesson in history.' Age, 6 February.

Australian Broadcasting Corporation. '7.30 Report.' 26 January 2006. Available from: http://www.abc.net.au/7.30/content/2006/s1556052.htm (accessed 5 February 2006).

—. 'Lateline.' 18 August 2006. Available from: http://www.abc.net.au/lateline/ content/2006/s1718847.htm (accessed 20 August 2006).

Barton, Keith C. and Linda S. Levstik. 2004. Teaching History for the Common Good. Mahwah, N.J.: Lawrence Erlbaum Associates, Inc.

Berk, Daniel. 2006. 'Letter.' The Australian, 19 August.

Bishop, Julie. 2006. 'Our classrooms need to make a date with the facts.' The Australian, 6 July.

Brett, Judith. 2005. 'Relaxed and Comfortable: The Liberal Party's Australia.' Quarterly Essay, no. 19.

Davison, Graeme. 2006. 'The New Politics of School History'. Symposium, no. 34 (October): 7.

Elder, Catriona. 2007. Being Australian: Narratives of National Identity. Sydney: Allen \& Unwin.

Grattan, Michelle. 2006. 'PM claims victory in culture wars.' The Age, 26 January. Hammett, Jenny. 2006. 'Letter.' The Australian, 21 August.

Harvey, Michael. 2006. 'PM wants new history.' Herald-Sun, 26 January.

Howard, John. 2006. Prime Minister John Howard's address to the National Press Club on January 25, 2006. Available from: http://heage.com.au/news/national/pms-speech/2006/01/25/ 1138066849045.html?page=fullpage\#contentSwapl (accessed 31 January 2006). 
Kelly, Miranda. 2006. 'Letter.' The Australian, 19 August.

Lee, Peter. 2001. 'Understanding History.' Paper presented at the Canadian Historical Consciousness in an International Context: Theoretical Frameworks conference, Centre for the Study of Historical Consciousness, University of British Columbia, Vancouver, BC. Available from: http://www.cshc.ubc.ca/pwias/viewabstract.php?10 (accessed 29 November 2007).

Levstik, Linda S. 2000. 'Articulating the Silences: Teachers' and Adolescents' Conceptions of Historical Significance.' In Knowing, Teaching and Learning History: National and International Perspectives, edited by Peter N. Stearns, Peter Seixas, and Sam Wineburg, 284-305. New York and London: New York University Press.

Létourneau, Jocelyn. 2006. 'Remembering Our Past: An Examination of the Historical Memory of Young Québécois.' In To the Past: History Education, Public Memory, and Citizenship in Canada, edited by Ruth Sandwell, 70-82. Toronto: University of Toronto Press.

Melleuish, Gregory. 2006. 'A better way of looking at our past.' The Australian, 30 January.

Olick, Jeffrey K. 2003. 'Introduction.' In States of Memory: Continuities, Conflicts, and Transformations in National Retrospection, edited by Jeffrey K. Olick, 1-16. Durham; London: Duke University Press.

Seixas, Peter. 1997. 'The Place of History within Social Studies.' In Trends and Issues in Canadian Social Studies, edited by Ian and Alan Sears Wright, 116-29. Vancouver: Pacific Educational Press.

—. 2002. 'The Purposes of Teaching Canadian History.' Canadian Social Studies 36, no. 2. Available from: http://www.quasar.ualberta.ca/css/ Css_36_2/Arpurposes_teaching_canadian_history.htm (accessed 15 July 2002).

—. 2006. 'What is Historical Consciousness.' In To the Past: History Education, Public Memory, and Citizenship in Canada, edited by Ruth Sandwell, 11-22. Toronto: University of Toronto Press.

Spillman, Lyn. 1997. Nation and Commemoration: Creating National Identities in the United States and Australia. Cambridge: Cambridge University Press.

Taylor, Tony and Carmel Young. 2003. 'Making History: A Guide for the Teaching and Learning of History in Australian Schools.' Canberra: Department of Education, Science and Training.

Wertsch, James V. 2002. Voices of Collective Remembering. Cambridge: Cambridge University Press. 
West, Andrew. 2006. 'Bad history: blame John Howard.' The Sydney Morning Herald, 31 January 2006. Available from: http://blogs.smh.com.au/ thecontrarian/archives/2006/01/bad_history_i_b.html (accessed 1 February 2006).

Wheaton, Grattan. 2006. 'Letter.' The Advertiser, 27 January.

Wineburg, Sam. 2001. Historical Thinking and Other Unnatural Acts: Charting the Future of Teaching the Past. Philadelphia: Temple University Press.

Wright, Clare. 2006. 'One story is rarely the whole story.' The Age, 24 July.

'Your Say: Facts or friction'. In The Age(online edition), 10 August 2006. Available from: http://blogs.theage.com.au/yoursay/archives/2006/08/ whos_history.html (accessed 10 August 2006).

\section{ENDNOTES}

1 John Howard, Prime Minister John Howard's address to the National Press Club on 25 January, 2006 (available from http://theage.com.au/news/national/pms-speech/2006/01/25/1138066849045.html? page=fullpage\#contentSwapl [accessed 31 January 2006]).

2 Ibid.

3 Ibid.

4 Michelle Grattan, 'PM claims victory in culture wars', The Age, 26 January 2006; Michael Harvey, 'PM wants new history', Herald-Sun, 26 January 2006.

5 Catriona Elder, Being Australian: Narratives of National Identity (Sydney: Allen \& Unwin, 2007), 303-7.

6 Howard, Prime Minister John Howard's address to the National Press Club on 25 January, 2006.

7 Benedict Anderson, Imagined Communities: Reflections on the Origin and Spread of Nationalism, 2nd ed. (London, New York: Verso, 1991).

${ }^{8}$ Gregory Melleuish, 'A better way of looking at our past', The Australian, 30 January 2006.

9 Janet Albrechtsen, 'Textbook case of making our past a blame game', The Australian, 1 February.

10 Grattan Wheaton, 'Letter', The Advertiser, 27 January 2006.

11 cited in Andrew West, 'Bad history: blame John Howard', The Sydney Morning Herald, 31 January 2006 (available from: http://blogs.smh.com.au/thecontrarian/archives/2006/01/bad_history_i_b.html [accessed 1 February 2006]).

12 See, for example: Jeffrey K. Olick, 'Introduction', in States of Memory: Continuities, Conflicts, and Transformations in National Retrospection, ed. Jeffrey K. Olick (Durham; London: Duke University Press, 2003); Lyn Spillman, Nation and Commemoration: Creating National Identities in the United States and Australia (Cambridge: Cambridge University Press, 1997); James V. Wertsch, Voices of Collective Remembering (Cambridge: Cambridge University Press, 2002).

13 Julie Bishop, 'Our classrooms need to make a date with the facts', The Australian, 6 July 2006. The participants at the Summit were: Andrew Barnett, Geoffrey Blainey, Geoffrey Bolton, David Boon, Bob Carr, Inga Clendinnen, Kate Darian-Smith, Nick Ewbank, John Gascoigne, Jenny Gregory, Gerard Henderson, John Hirst, Jackie Huggins, Paul Kelly, Jennifer Lawless, Mark Lopez, Gregory Melleuish, Margo Neale, Geoffrey Partington, Lisa Paul, Peter Stanley, Tom Stannage and Tony Taylor.

14 Jenny Hammett, 'Letter', The Australian, 21 August 2006.

15 Miranda Kelly, 'Letter', The Australian, 19 August 2006.

16 Judith Brett, 'Relaxed and Comfortable: The Liberal Party's Australia', Quarterly Essay, no. 19 (2005).

17 Howard, Prime Minister John Howard's address to the National Press Club on 25 January, 2006.

18 Australian Broadcasting Corporation, '7.30 Report', 26 January 2006 (available from: http://www.abc.net.au/7.30/content/2006/s1556052.htm [accessed 5 February 2006]).

19 Graeme Davison, 'The new politics of school history', Symposium, no. 34 (October 2006): 7. 
20 Annabel Astbury, 'A lesson in history', The Age, 6 February 2006.

21 Daniel Berk, 'Letter', The Australian, 19 August 2006.

22 'Your Say: Facts or friction', The Age (online edition), 10 August 2006 (available from: http://blogs.theage.com.au/yoursay/archives/2006/08/whos_history.html [accessed 10 August 2006]).

23 Australian Broadcasting Corporation, 'Lateline', 18 August 2006 (available from: http://www.abc.net.au/lateline/content/2006/s1718847.htm [accessed 20 August 2006]).

24 Clare Wright, 'One story is rarely the whole story', The Age, 24 July 2006.

25 Tony and Carmel Young Taylor, 'Making History: A Guide for the Teaching and Learning of History in Australian Schools' (Canberra: Department of Education, Science and Training, 2003), 8.

26 Peter Seixas, 'The Place of History within Social Studies', in Trends and Issues in Canadian Social Studies, ed. Ian Wright and Alan Sears (Vancouver: Pacific Educational Press, 1997), 116-17.

27 Sam Wineburg, Historical Thinking and Other Unnatural Acts: Charting the Future of Teaching the Past (Philadelphia: Temple University Press, 2001), 79.

28 Peter Seixas, 'The Purposes of Teaching Canadian History', Canadian Social Studies, 36, no. 2 (2002) (available from: http://www.quasar.ualberta.ca/css/Css_36_2/Arpurposes_teaching_canadian_history.htm [accessed 15 July 2002]). See also: Jocelyn Létourneau, 'Remembering Our Past: An Examination of the Historical Memory of Young Québécois', in To the Past: History Education, Public Memory, and Citizenship in Canada, ed. Ruth Sandwell (Toronto: University of Toronto Press, 2006); Peter Seixas, 'What is Historical Consciousness,' in To the Past: History Education, Public Memory, and Citizenship in Canada, ed. Ruth Sandwell (Toronto: University of Toronto Press, 2006), 14.

29 Peter Lee, 'Understanding History' (paper presented at the Canadian Historical Consciousness in an International Context: Theoretical Frameworks conference, Centre for the Study of Historical Consciousness, University of British Columbia, Vancouver, BC, 2001) (available from: http://www.cshc.ubc.ca/pwias/viewabstract.php? 10 [accessed 29 November 2007]).

30 Keith C. Barton and Linda S. Levstik, Teaching History for the Common Good (Mahwah, N.J.: Lawrence Erlbaum Associates, Inc., 2004), 61.

31 Linda S. Levstik, 'Articulating the Silences: Teachers' and Adolescents' Conceptions of Historical Significance', in Knowing, Teaching and Learning History: National and International Perspectives, ed. Peter N. Stearns, Peter Seixas, and Sam Wineburg (New York and London: New York University Press, 2000).

32 This research project has been funded by a Discovery Grant from the Australian Research Council. The investigators are Tony Taylor and Anna Clark from Monash University, Stuart Macintyre from the University of Melbourne, and Carmel Young from the University of Sydney. The project began in September 2005 and is due to finish in 2008. The names of students and teachers have been changed.

33 Interview with students, independent Islamic school, Sydney, 23 August 2006.

34 'Jill', public high school, New South Wales Central Coast, 22 August 2006.

35 'Les', public high school, New South Wales Central Coast, 22 August 2006.

36 'Chen', public girls' high school, Sydney, 21 August 2006.

37 'Annie', independent girls' school, Canberra, 17 August 2006.

38 'Lily', independent girls' school, Brisbane, 24 July 2006.

39 'Jeff', Catholic boys' school, Brisbane, 25 July 2006.

40 Interview with students, public senior college, Perth, 24 May 2006.

41 Interview with students, public high school, Darwin, 21 June 2006.

42 'Margaret', history teacher, public high school, Hobart, 4 May 2006.

43 'Mary', history teacher, public high school, Brisbane, 26 July 2006.

44 'Stephen', history teacher, Catholic boys' school, Adelaide, 15 June 2006.

45 'Andie', public girls' school, Sydney, 21 August 2006.

46 Interview with students, public high school, New South Wales Central Coast, 22 August 2006. 